\title{
Inovasi Perpustakaan Muhammadiyah-'Aisyiyah Pandemi Covid-19: Sebuah Studi Literatur Bunga Rampai \\ Perguruan Tinggi (PTMA) Menghadapi
}

\author{
Gretha Prestisia Rahmadian Kusuma* \\ Universitas Ahmad Dahlan, Yogyakarta, Indonesia
}

Paper type:

Review article

\section{Article history:}

Received October 14, 2021

Revised November 8, 2021

Accepted November 8, 2021

Keywords:

- FPPTMA

- Covid-19 pandemic

- PTMA

- Library innovation

\section{Abstract}

Introduction. The COVID-19 pandemic has had an impact on education systems around the world, including Indonesia. The government carried out temporary closure of public services to reduce the number of additional cases. One of the community services affected is the library as a support for education. As a supporter of education, the perceived impact is the non-utilization of services in the library. Efforts made by the library to continue to provide services are by changing the system and management mechanism in the library. This paper aims to find out the innovations and strategies implemented in several PTMA libraries in the era of the Covid-19 pandemic.

Methodology. This study uses a literature review to collect data and documentation to support the analysis.

Result. The result of this paper is that PTMA library librarians must be able to use facilities or technology to serve the academic community.

Conclusion. The COVID-19 pandemic has not only hurt society. The other side of the Covid-19 pandemic is being able to develop competence through online seminars. In addition, the handling of the COVID-19 pandemic, which is gradually improving, has forced libraries to reopen services while still implementing health protocols to suppress the rate of transmission.
\end{abstract}

\section{Pendahuluan}

Forum Perpustakaan Perguruan Tinggi Muhammadiyah Aisyiyah (FPPTMA) adalah salah satu forum perpustakaan perguruan tinggi di bawah naungan organisasi bernama Muhammadiyah dan 'Aisyiyah. FPPTMA dibentuk pada tahun 2004 dengan nama organisasi Forum Silaturrahim Perpustakaan Perguruan Tinggi Muhammadiyah Aisyiyah (FSPPTMA), kemudian di tahun 2017 berubah menjadi FPPTMA. Jumlah perguruan tinggi di bawah naungan organisasi Muhammadiyah-'Aisyiyah adalah 162 instansi (Lhoksumawe, 2020), namun jumlah perpustakaan yang terhimpun di dalam FPPTMA hanya 89 (FPPTMA, 2021), sehingga belum semua perpustakaan perguruan tinggi Muhammadiyah-'Aisyiyah tergabung dalam FPPTMA.

FPPTMA aktif kembali di tahun 2012 di bawah kepemimpinan bapak Drs. Lasa HS beliau adalah kepala perpustakaan Universitas Muhammadiya Yogyakarta (UMY) hingga saat ini. Kiprah beliau di dunia kepustakawanan dan perpustakaan banyak diimplementasikan untuk pengembangan perpustakaan melalui pustakawan Perguruan Tinggi

\footnotetext{
* Corresponding author.

Email address: grethaprestisia@staff.uad.ac.id (G. P. R. Kusuma)
} 
Muhammadiyah Aisyiyah (PTMA). Upaya untuk selalu memberikan layanan dengan semboyan "urip-uripono Muhammadiyah" yang menjadikan anggotanya harus ikhlas beramal untuk melayani pemustaka dalam segala hal.

Muhammadiyah merupakan gerakan Islam dakwah amar ma'ruf nahi munkar dan tajdid (pembaruan tentang pokok ajaran Islam) yang bersumber pada al-Qur'an dan as Sunnah as-Sohihah yang didirikan oleh KH. Akhmad Dahlan sejak 12 November 1912 (Muhammadiyah, 2021), sedangkan 'Aisyiyah adalah organisasi otonom bagi wanita Muhammadiyah yang didirikan pada 19 Mei 1917 (Pimpinan Pusat 'Aisyiyah, 2021). Usia organisasi tersebut hampir menginjak abad ke-2, tentunya organisasi ini bukan tidak mungkin memiliki informasi berupa tulisan, artefak atau arsip statis yang merupakan rekam jejak pendiri organisasi.

Muhammadiyah memiliki Library, Archieves, and Museum (LAM), yaitu sebuah bangunan berupa Museum Muhammadiyah yang memadukan antara perpustakaan, arsip dan museum sebagai penyedia jasa layanan informasi di lingkungan Muhammadiyah (Jubaidi, 2020). Museum Muhammadiyah kelak dapat memberikan esensi sebagai wajah masa lalu yang kental dengan budaya. Dengan adanya museum ini, diharapkan peran maupun tipologi Muhammadiyah yang sampai saat ini dikenal sebagai organisasi massa yang Islam modern akan tampak lebih empiris melalui berbagai nilai akulturasi budaya. LAM merupakan salah satu layanan yang diberikan kepada masyarakat berupa informasi yang tersimpan di museum. LAM sebagai lembaga yang menghimpun koleksi warisan budaya Muhammadiyah-'Aisyiyah menjadi rujukan kebutuhan informasi mengenai Muhamadiyah-'Aisyiyah. Selain itu, perguruan tinggi Muhammadiyah-'Aisyiyah memiliki perpustakaan yang digunakan sebagai penunjang pendidikan. Layanan perpustakaan perguruan tinggi lazimya menunjang tri dharma atau catur dharma perguruan tinggi. Selain itu, perpustakaan adalah penunjang unsur pendidikan sebagai media penyebaran informasi. Pustakawan adalah pemeran utama dalam menyediakan segala kebutuhan pemustaka, sehingga pemustaka adalah barometer tingkat keberhasilan sebuah layanan perpustakaan. Di era keterbukaan akses informasi seperti sekarang ini, perpustakaan berlomba-lomba untuk membuat sebuah terobosan atau inovasi yang disesuaikan dengan perkembangan teknologi. Perlahan, layanan offline mulai beralih ke online.

Berbicara mengenai layanan online, saat ini dunia sedang dihadapkan pada wabah penyebaran virus Covid-19. Lebih dari satu tahun lamanya Indonesia dan hampir seluruh belahan dunia berada di bawah ancaman penyebaran Corona Virus Desease 2019 (Covid19). Berdasarkan peta sebaran penyebaran virus, hingga saat ini ada total 1.775 .220 orang terkonfirmasi positif, dan 49.328 orang diantaranya meninggal akibat paparan virus ini (Satuan Tugas Penanganan COVID-19, 2021). Berbagai upaya telah dilakukan pemerintah untuk menanggulangi penyebaran virus dengan salah satunya adalah jaga jarak (physical distancing). Upaya ini setidaknya menekan laju penyebaran meskipun membawa dampak yang buruk bagi tatanan kehidupan masyarakat. Dunia pendidikan dan segala penunjang pendidikan seolah-olah berjalan tidak pada mestinya. Perpustakaan merupakan salah satu bagian dari penunjang di dalam dunia pendidikan, tak terelakkan pula bahwa perpustakaan terkena imbas atas penyebaran virus ini.

Penyebaran virus Covid-19 menggiring perpustakaan untuk berinovasi dan berkreasi lebih maksimal. Di saat perpustakaan tidak memikirkan tentang menyebarnya virus ini, perpustakaan harus tetap eksis sebagai penghimpun, pengelola, penyebar informasi. Pustakawan senantiasa mengunakan layanan secara online hingga penerapan protokol kesehatan di manapun dan kapanpun. Perpustakaan membatasi akses kunjungan secara fisik, layanan peminjaman tidak bisa dilakukan dengan leluasa, namun di sisi lain perpustakaan secara leluasa memberikan akses online tanpa batas. Di tengah maraknya akses online tidak terbatas ini, beberapa pemustaka dari kalangan santri masih tidak diperbolehkan untuk memanfaatkan gadget dalam kesehariannya (Winata et al., 2019), 
mengingat di tengah padatnya banjir informasi, ternyata masih ada yang tetap membatasi akses informasi. Jika membahas mengenai peran pustakawan sebagai aktor yang menjembatani antara informasi dengan pemustaka (Winata, 2019), maka pustakawan memiliki peran penting untuk melakukan kegiatan diseminasi informasi dengan harapan bahwa santri sebagai pemustaka tetap memiliki informasi yang terbaru.

Terlepas dari kajian yang dilakukan oleh penulis, pandemi ini memacu kinerja pustakawan untuk tetap melayani kebutuhan pemustaka. Berbagai upaya dilakukan perpustakaan untuk memberikan layanan terbaiknya. Oleh karena itu, penulis membahas inovasi perpustakaan dan peran pustakawan PTMA dalam menghadapi pandemi Covid19. Metode penulisan yang digunakan adalah menggunakan metode kajian literatur dalam bunga rampai dengan judul "New Normal Innovations: Adaptasi Perpustakaan Perguruan Tinggi Muhammadiyah "Aisyiyah" serta menggunakan beberapa dokumentasi untuk mendukung penulisan.

\section{Pembahasan}

Ranganathan menyatakan bahwa perpustakaan adalah salah satu organisasi yang tumbuh (Hendrawan, 2013). Sejak sebelum pandemi beberapa perpustakaan telah menggunakan layanan berbasis online, perpustakaan tidak hanya saja melayankan buku sebagai sumber utama penyebaran informasi. Seperti adanya Eprints dan dSpace yang digunakan sebagai media untuk menghimpun koleksi digital serta database online yang dilanggan di perpustakaan. Perpustakaan memerlukan inovasi untuk memberikan layanan kepada sivitas akademik, pandemi ini seolah-olah semakin membenarkan dalil Ranganathan di atas. Inovasi yang dapat dilakukan oleh perguruan tinggi adalah sematamata untuk bisa memenuhi kebutuhan informasi pemustaka.

Berdasarkan kajian literatur yang dilakukan oleh penulis, inovasi yang dilakukan perpustakaan PTMA melalui bunga rampai dengan judul "New Normal Innovation: Adaptasi Perpustakaan Perguruan Tinggi Muhammadiyah-Aisyiyah" membahas layanan perpustakaan selama pandemi, baik membahas persiapan, penerapan protokol kesehatan serta layanan yang diberikan selama pandemi. Berdasarkan 15 artikel tersebut terbagi menjadi empat tema yakni: membahas mengenai pengelolaan dokumen sebanyak satu artikel, membahas mengenai profesionalisme pustakawan sebanyak tiga artikel, membahas kegiatan literasi informasi sebanyak tiga artikel, dan sisanya sembilan artikel membahas tentang metode layanan perpustakaan.

\subsection{Inovasi Perpustakaan PTMA}

Kamus Besar Bahasa Indonesia (Badan Pengembangan dan Pembinaan Bahasa, 2021) menyatakan bahwa inovasi adalah penemuan baru yang berbeda dari yang sudah ada atau yang sudah dikenal sebelumnya (gagasan, metode, atau alat). Undang-Undang No.19 tahun 2002 menyatakan bahwa inovasi adalah kegiatan penelitian, pengembangan dan atau pun perekayasaan yang dilakukan dengan tujuan melakukan pengembangan penerapan praktis nilai dan konteks ilmu pengetahuan yang baru ataupun cara baru untuk menerapkan ilmu pengetahuan dan teknologi yang sudah ada ke dalam produk ataupun proses produksinya (Sujatna, 2018).

Inovasi dapat diartikan sebagai suatu perubahan yang sifatnya khusus (specific) yang mengandung kebaharuan (novelty), disengaja melalui suatu program yang direncanakan terlebih dahulu (planned and deliberate) serta dirancang untuk mencapai tujuan yang diinginkan melalui suatu sistem tertentu (goals of the system)(Gottlieb, 1965). Inovasi merupakan suatu gagasan yang baru diterapkan untuk memprakarsai atau memberbaiki 
suatu produk atau proses dan jasa (Mukerji \& Robbins, 1994). Mukerji \& Robbins (1994) memfokuskan pada tiga hal utama, pertama yaitu suatu olah pikir dalam mengamati suatu fenomena yang terjadi; kedua, produk dan jasa yaitu hasil langkah lanjutan dari gagasan baru yang ditindaklanjuti dengan berbagai aktivitas, kajian, penelitian dan percobaan sehingga melahirkan konsep yang lebih konkret dalam bentuk produk dan jasa yang siap dikembangkan; dan ketiga adalah upaya perbaikan, yaitu usaha sistematis untuk melakukan penyempurnaan dan melakukan perbaikan sehingga dirasa kebermanfaatannya.

Inovasi yang dilakukan oleh perpustakaan setidaknya memiliki ciri-ciri yang menunjukkan beberapa kriteria. Mukerji \& Robbins (1994) menyatakan bahwa ciri-ciri inovasi antara lain: (1) memiliki kekhasan/khusus artinya suatu inovasi memiliki ciri yang khas dalam arti ide, program, tatanan, sistem, termasuk kemungkinan hasil yang diharapkan; (2) memiliki ciri atau unsur kebaruan, dalam arti suatu inovasi harus memiliki karakteristik sebagai sebuah karya dan buah pemikiran yang memiliki kadar orisinalitas dan kebaruan; (3) program inovasi dilaksanakan melalui program yang terencana, dalam arti suatu inovasi dilakukan melalui suatu proses yang tidak tergesa-gesa, namun kegiatan inovasi dipersiapkan secara matang dengan program yang jelas dan direncakan terlebih dahulu; dan (4) inovasi yang digulirkan memiliki tujuan, program inovasi yang dilakukan harus memiliki arah yang ingin dicapai, termasuk arah dan strategi untuk mencapai tujuan tersebut.

Kementerian Pendidikan dan Kebudayaan menyatakan bahwa pembelajaran dapat dilakukan secara campuran (hybrid learning) dalam jaringan dan tatap muka, sesuai dengan prosedur protokol kesehatan yang ketat (Kementerian Pendidikan dan Kebudayaan Republik Indonesia, 2020). Keputusan tersebut membuat sebagian besar mahasiswa tidak berada di area perkuliahan, terbukti dengan ditunjukkan dengan adanya gagasan yang disampaikan oleh Nisak (2020) bahwa dalam rangka meminimalisir kunjungan fisik ke perpustakaan, Perpustakaan UNISA membuat sebuah inovasi melalui financial technology (fintech) berupa M-Banking, OVO, LinkAja, T-Cash, DANA. Hal ini dirasa perlu dibuatkan untuk mendukung proses pembayaran keterlambatan denda. Mahasiswa yang masih dikenai denda tidak bisa mendapatkan surat keterangan bebas perpustakaan jika masih ada peminjaman. Dengan adanya fasilitas fintech tersebut, koleksi yang masih terpinjam dapat dikirimkan melalui ekspedisi.

Inovasi lain yang bisa dilakukan oleh pustakawan dalam mendukung proses pembelajaran adalah dengan melakukan proses alih media koleksi. Koleksi cetak yang dialihmediakan dan disebarluaskan kepada mahasiswa dapat diakses melalui media sosial. Indrakasih (2020) membahas mengenai alih media melalui Youtube dan podcast. Youtube adalah media pandang dengar, sedangkan podcast merupakan media dengar karena podcast adalah hasil rekaman audio. Podcast dapat menggunakan aplikasi Anchor yang bisa diunduh secara bebas melalui platform tertentu. Podcast berbeda dengan radio, karena radio membutuhkan frekuensi untuk dapat mendengarkan siaran, sedangkan podcast bisa didengarkan di manapun dan kapanpun. Nur (2020) membahas mengenai alih media modul menjadi video tutorial dan bisa diakses melalui Youtube, sedangkan Indrakasih (2020) menulis cara pemanfaatan podcast melalui aplikasi Anchor yang digunakan untuk story telling. Anchor dapat mendukung perekaman suara berupa puisi dan juga bisa digunakan untuk pengumuman.

Tujuan dilakukannya inovasi perpustakaan antara lain juga memberikan kemudahan bagi pemustaka dalam menelusur informasi. Pemberlakuan bekerja dan belajar dari rumah, pembatasan fisik, dan larangan berkumpul menjadi kendala pemustaka untuk memperoleh informasi cetak, padahal perpustakaan merupakan tempat diskusi yang paling dicari oleh sivitas akademika sebelum masa pandemi. Peminjaman, pengembalian, dan perpanjangan secara drive-thru menjadi solusi bagi sivitas akademik yang berada di 
area perkuliahan. Hal ini senada dilakukan di berbagai perpustakaan (Universitas Muhammadiyah Purwokerto, Universitas Muhammadiyah Jakarta, Stikes Muhammadiyah Gombong, Universitas 'Aisyiyah Yogyakarta). Dengan membuat inovasi drive-thru(setelah pemustaka memesan koleksi melalui laman pre-order), maka petugas perpustakaan melakukan pengiriman melalui ekspedisi atau pengiriman lain sesuai dengan penawaran di perpustakaan.

Dalam bunga rampai ini, Rahmawati (2020) membahas penambahan fitur layanan di 'SIMP TT' (semacam portal akademik) yang bisa dilakukan untuk melakukan sirkulasi online. Anindieta (2020) mengemukakan bahwa untuk meminjam koleksi, bisa dilakukan dengan melakukan pemesanan melalui media sosial terlebih dahulu (seperti Instagram, WhatsApp, Email, Facebook dan Twitter) setelah mengetahui ketersediaannya melalui katalog online (OPAC). Sistem peminjaman seperti itu tentu tidak berlaku jika mahasiswa tidak berada di area perkuliahan sehingga perpustakaan mengembangkan koleksi dengan menambah jumlah koleksi digitalnya. Menambah jumlah langganan atau mengunduh koleksi yang memang dapat diunduh secara gratis adalah strategi untuk tetap menambah jumlah koleksi dan menyebarkan informasi.

Anggrahini (2020) yang merupakan pustakawan UM Pontianak merancang digitalisasi koleksi. Rancangan inipun tak luput dari berbagai pertimbangan akses mengenai copyright, karena ketika mendigitalisasikan koleksi cetak dan disebarluaskan akan pasti berurusan dengan Undang-Undang Republik Indonesia Nomor 28 tentang Hak Cipta (2014) pasal 9 ayat 2 yang berbunyi bahwa setiap orang yang melaksanakan hak ekonomi sebagaimana dimaksud pada ayat (1) wajib mendapatkan izin pencipta atau pemegang hak cipta (Oktavira, 2019). Oleh sebab itu, e-book yang merupakan adaptasi dari buku karya pencipta atau pemegang hak cipta, maka perpustakaan wajib mendapatkan izin terlebih dahulu dari pencipta atau pemegang hak cipta buku tersebut.

Perpustakaan digital memberi kemudahan bagi para pemustaka untuk memperoleh informasi, sehingga di manapun pemustaka khususnya yang tidak berada di area perkuliahan dapat memanfaatkan fasilitas atau layanan yang diberikan oleh perpustakaan. Hal ini senada dengan Setiawati (2020) bahwa pemustaka mudah mendapatkan akses informasi. Inovasi yang dituliskan oleh Hariri (2020) dengan melakukan transformasi di perpustakaan Universitas Muhammadiyah Purwokerto (UMP) dengan membuat aplikasi yang bisa diunduh melalui Play Store dan Windows. Aplikasi ini memiliki e-reader yang memiliki fungsi mengindeks berbagai model sitasi sehingga pemustaka mudah untuk membaca koleksi yang tersimpan di ‘mLibrary' UMP.

Inovasi layanan yang diterapkan di perpustakaan PTMA berdasarkan bunga rampai di atas disesuaikan dengan kondisi perguruan tinggi masing-masing. Inovasi harus memiliki kekhasan dan keterbaruan, tentunya hal ini harus sejalan atau sesuai dengan sasaran layanan yakni pemustaka. Inovasi merupakan wujud dari profesionalisme pustakawan sebagai bukti dari kompetensi yang dimiliki.

\subsection{Profesionalisme Pustakawan PTMA}

Profesionalisme pustakawan tercermin pada kemampuan (pengetahuan, pengalaman, keterampilan) dalam mengelola dan mengembangkan pelaksanaan pekerjaan di bidang kepustakawanan serta kegiatan terkait lainnya secara mandiri. Kualitas hasil pekerjaan inilah yang akan menentukan profesionalisme mereka. Pustakawan profesional dituntut menguasai bidang ilmu kepustakawanan, serta memiliki keterampilan dalam melaksanakan tugas/pekerjaan kepustakawanan, melaksanakan tugas/pekerjaannya dengan motivasi yang tinggi yang dilandasi oleh sikap dan kepribadian yang menarik demi mencapai kepuasan pengguna (Purwono, 2013). 
Profesionalisme mendukung terwujudnya inovasi perpustakaan, inovasi muncul dari ide atau gagasan dari pelaku utama perpustakaan, yakni pustakawan. Inovasi tidak akan berjalan tanpa adanya persetujuan kebijakan dari pimpinan. Seorang pustakawan harus melakukan inovasi dengan menyesuaikan kondisi lapangan, misalnya saat ini karakteristik pemustaka adalah generasi $Z$, mereka lahir di saat informasi dapat diakses dari manapun. Perpustakaan dengan konsep tradisional hanya mengandalkan kunjungan fisik, pasti akan tertinggal. Informasi tidak hanya dicetak dan ditempel di papan pengumuman yang kemungkinan pemustaka tidak membaca pengumuman itu. Selain ditempel pustakawan harus berkenalan dengan media sosial seperti Instagram yang digunakan untuk media pengumuman secara online. Oleh karena itu, tidak hanya inovasi layanan perpustakaan saja yang harus diupdate tetapi kompetensi pustakawan harus selalu dikembangkan.

Era pandemi tidak menyurutkan pustakawan untuk mengembangkan kompetensi yang dimiliki. Banyak forum perpustakaan dan organisasi profesi yang mengadakan web seminar atau lebih sering disebut webinar. Layyina (2020) menyatakan bahwa selama pandemi banyak webinar yang diikuti, webinar memberikan dampak positif dan tentu pula negatif. Positifnya dapat mengembangkan wawasan meski pandemi, negatifnya adalah lokasi yang digunakan untuk ikut serta dalam webinar kurang memadai (sinyal kurang baik).

Totalitas yang dilakukan Irkhamiyati (2020) untuk tetap memberikan layanan terbaiknya kepada pemustaka adalah dengan mengimplementasikan pekerjaan dari rumah. Melakukan proses pengadaan koleksi dengan proses pengiriman dan pembayaran ke rumah atau di perpustakaan yang sebelumnya dilakukan perjanjian. Melakukan proses kerjasama dengan pihak internal universitas dan melakukan layanan secara daring.

Pustakawan Universitas Muhammadiyah Sukabumi menyatakan bahwa untuk melayani kebutuhan pemustaka, perpustakaan harus benar-benar memahami karakteristik masing-masing pemustaka (Sundari, 2020). Tentunya hal ini menjadi tantangan sendiri bagi perpustakaan, selain harus membuat aturan-aturan terkait dengan protokol kesehatan, yang harus dilakukan adalah dengan tetap memprioritaskan kondisi psikologi SDM perpustakaan untuk berhadapan dengan Teknologi Informasi (TI) yang tidak semua pustakawan familiar dengan penggunaan TI tersebut.

Meskipun dalam keadaan pandemi, kreativitas pustakawan tetap harus dikembangkan untuk melayani kebutuhan pemustaka. Banyak fasilitas online yang bisa digunakan untuk menambah wawasan pustakawan. Web seminar, call for paper, penulisan karya ilmiah, pemilihan pustakawan berprestasi adalah salah satu upaya yang bisa dilakukan pustakawan untuk menunjukkan kompetensi yang dimiliki. Literasi informasi adalah salah satu kegiatan perpustakaan yang dapat digunakan untuk menangkal hoaks seputar pemberitaan penyebaran virus ini.

\subsection{Literasi Informasi Perpustakaan PTMA}

Literasi informasi pustakawan diperlukan untuk pengembangan kompetensi dan perpustakaan. Pustakawan tidak akan bisa mengembangkan kompetensi dan perpustakaannya tanpa melihat fenomena tentang keduanya. Ketika dihadapkan dengan kondisi pandemi seperti ini, mencari informasi melalui media adalah hal yang lazim dilakukan. Kegiatan literasi informasi tetap bisa dilakukan oleh perpustakaan dengan menggunakan media berbeda, jika sebelum pandemi pemustaka bisa bertatap muka dengan para tutor dan bisa saling diskusi, namun kali ini kegiatan literasi informasi yang dilakukan bisa melalui elearning, Zoom, Google Meet atau aplikasi lain pendukung kegiatan literasi informasi. Contoh kegiatan literasi informasi yang dapat dilakukan antara lain adalah mengadakan pelatihan cara penelurusan sumber informasi online, pendidikan pemakai serta webinar. 
Edukasi tentang perkembangan Covid-19 pun bisa disisipkan melalui layanan ini. Tidak serta merta seorang pustakawan hanya menyampaikan informasi tentang layanan di perpustakaan. Setiobudi (2020) menuliskan adanya pemberitaan mengenai Covid-19 membuat masyarakat resah mengingat virus ini belum banyak penelitian sehingga cara, pengobatan, pemulihan pun masih dalam tahap penelitian. Upaya yang dilakukan oleh perpustakaan untuk memberikan pengarahan kepada masyarakat yang tujuannya untuk memberikan pemahaman kepada masyarakat. Oleh sebab itu, kegiatan literasi informasi yang dilakukan oleh perpustakaan juga bertujuan memberikan edukasi kepada masyarakat tentang Covid-19.

Prasetyo (2020) juga mengungkapkan hal yang sama, bahwa pemberitaan yang terlalu dibesar-besarkan akan menimbulkan keresahan masyarakat. Tentunya hal ini akan berpengaruh terhadap psikologis masyarakat. Perpustakaan memiliki andil besar untuk mengurangi disinformasi dengan cara mempromosikan kesadaran masyarakat akan kesehatan berupa himbauan untuk menerapkan protokol kesehatan, menjaga jarak dan menjaga imunitas tubuh, selanjutnya mendukung para peneliti dengan menyediakan literatur dan memaksimalkan layanan kepada pengguna.

Mengelola dan menyebarkan informasi bukan perihal mudah, namun sebagai pustakawan dan tenaga perpustakaan hal itu adalah sebuah tantangan. Pustakawan dan tenaga perpustakaan yang memiliki karateristik gen $X$ yakni mereka yang lahir antara tahun 1961-1980 (Goeyardi, 2020), sehingga memiliki pola pikir yang berbeda dengan karakteristik generasi milenial saat ini. Pustakawan dan tenaga perpustakaan harus memiliki kecakapan dan ketepatan menjawab pertanyaan pemustaka serta mereka harus dapat memanfaatkan teknologi di era digital seperti ini. Menyampaikan informasi kepada pemustaka harus menggunakan dasar agar informasi yang disampaikan tidak mengandung hoaks. Kompetensi pustakawan untuk menyumbang ide, gagasan untuk keberlangsungan perpustakaan adalah poin penting terwujudnya layanan berbasis pemenuhan kebutuhan pemustaka (user oriented). Pandemi mengajak pustakawan untuk senantiasa memberikan layanan di tengah keterbatasan fasilitas, pembatasan kunjungan secara fisik dan keterbatasan layanan yang diberikan. Layanan online menjadi salah satu solusi untuk mempertahankan eksistensi perpustakaan.

\subsection{Protokol Kesehatan}

Anjuran penerapan protokol kesehatan yang senantiasa digalakkan menjadi salah satu upaya untuk melindungi diri dari infeksi virus Covid-19. Berdasarkan Keputusan Menteri Kesehatan Republik Indonesia (2020) tentang protokol kesehatan bagi masyarakat di tempat dan fasilitas umum menganjurkan bahwa protokol kesehatan diterapkan dengan melindungi kesehatan individu dan masyarakat. Perlindungan kesehatan individu meliputi (1) menggunakan alat pelindung diri berupa masker yang menutupi hidung dan mulut hingga dagu; (2) membersihkan tangan secara teratur dengan cuci tangan pakai sabun dengan air mengalir atau menggunakan cairan antiseptik berbasis alkohol atau hand sanitizer; (3) menjaga jarak minimal satu meter dengan orang lain untuk menghindari terkena droplet dari orang yang bicara, batuk, atau bersin, serta menghindari kerumunan, keramaian, dan berdesakan; dan (4) meningkatkan daya tahan tubuh dengan menerapkan Perilaku Hidup Bersih dan Sehat (PHBS) seperti mengkonsumsi gizi seimbang, aktivitas fisik minimal 30 menit sehari dan istirahat yang cukup (minimal 7 jam), serta menghindari faktor risiko penyakit.

Adapun perlindungan kesehatan masyarakat meliputi (1) pencegahan (prevent) melalui kegiatan promosi kesehatan (promote), kegiatan perlindungan (protect); (2) penemuan kasus (detect) melalui Fasilitasi dalam deteksi dini untuk mengantisipasi penyebaran COVID-19, melakukan pemantauan kondisi kesehatan; (3) penanganan secara 
cepat dan efektif (respond). Potensi penularan COVID-19 di tempat dan fasilitas umum disebabkan adanya pergerakan, kerumunan, atau interaksi orang yang dapat menimbulkan kontak fisik. Peran pengelola, penyelenggara, atau penanggung jawab tempat dan fasilitas umum sangat penting untuk perlindungan kesehatan masyarakat.

Perpustakaan menghimbau adanya penerapan protokol kesehatan ketat selama memberikan layanan. Penerapan protokol kesehatan berupa penambahan sekat di meja layanan, penggunaan face shield, penggunaan hand sanitizer, pengurangan jumlah kursi baca, pembatasan kunjungan, stiker himbauan wajib menggunakan masker dan jaga jarak. Penanganan Satgas Covid-19 beserta para tenaga kesehatan sudah tidak lagi diragukan, bahkan risiko terpapar virus ini adalah konsekuensi dari sebuah profesi. Anjuran untuk menerapkan protokol kesehatan semakin digencarkan, bahkan saat ini dianjurkan untuk menggunakan masker dua lapis dengan lapis pertama adalah masker medis, dan lapis dua adalah dengan menggunakan masker kain (Oktavia, 2021).

Perpustakaan UMP melakukan transformasi berupa penataan ulang dengan mengubah tata ruang, mengurangi jumlah ketersediaan kursi, dan menempel himbauan prokes. Perpustakaan Universitas Muhammadiyah Sukabumi (UM Sukabumi) pun juga menerapkan hal demikian, melakukan penataan ulang ruang baca sebagai upaya pencegahan penyebaran virus. Perpustakaan UM Sukabumi mempersiapkan adanya layanan terbatas yang meliputi jam kunjung 09.00-14.00 WIB dengan kapasistas pengunjung 25 orang dan setiap pemustaka wajib melakukan pengecekan suhu, menggunakan hand sanitizer, serta disediakan linkpemesanan jika menggunakan layanan sirkulasi.

IFLA (2020) menyarankan bahwa jika memang di wilayah terdampak penyebaran Covid-19 belum normal, perpustakaan tidak dianjurkan untuk membuka layanan. Contoh di sebagian besar perpustakaan, sejauh ini perpustakaan membuka layanan secara bertahap, menerapkan layanan baru, kegiatan. Perpustakaan akan melanjutkan layanannya dengan catatan bahwa semua tahapan yang dilalui di rasa aman (IFLA, 2020). Dengan demikian, perpustakaan membuka layanan dengan beberapa catatan seperti menerapkan protokol kesehatan, mengurangi jumlah kursi untuk membaca, memberi sekat di meja layanan.

\subsection{Peran Pustakawan di Era New Normal}

Terbatasnya layanan yang diberikan perpustakaan kepada pemustaka tidak menjadikan pustakawan untuk tidak berpartisipasi di era pandemi. Bahkan IFLA (2020) menyatakan bahwa, pustakawan dapat dipindahtugaskan ke sub kerja lain dengan berbekal kemampuan manajemen informasi yang dimiliki. Selain itu, IFLA (2020) menekankan adanya amnesti/pembebasan denda buku yang dipinjam.

Peran pustakawan di era pandemi Covid-19 dapat dilakukan dengan (1) memberikan edukasi kepada civitas akademik mengenai virus Covid-19 tentang bagaimana cara penyebaran, pencegahan serta penanganan yang diinfokan melalui kegiatan literasi informasi; (2) menjadi produsen informasi melalui kajian-kajian yang diikuti saat kegiatan webinar, workshop khusunya bidang perpustakaan, dokumentasi, dan informasi (pusdokinfo); (3) menganalisis keterpakaian koleksi digital sebagai sarana untuk mengadakan koleksi digital; (4) menyediakan fasilitas layanan ekstensi online seperti bimbingan akses online kepada civitas; dan (5) melakukan kemas ulang informasi dan disebarluaskan dalam bentuk video tutorial, infografis menggunakan media sosial yang mudah dijangkau seperti melalui Instagram, website, email, atau WhatApp group. 


\section{Simpulan}

Bunga Rampai yang tertuang dalam buku ini adalah bentuk apresiasi FPPTMA kepada perpustakaan dan pustakawan yang mampu memberikan layanan kepada civitas akademik di era pandemi dengan inovasi yang disesuaikan dengan kemampuan perpustakaan dan pustakawannya. Perpustakaan menjadi rujukan bagi sivitas akademik dalam proses pembelajaran. Dampak positif dari adanya pandemi adalah pustakawan dituntut untuk mahir teknologi informasi, kreativitas untuk menciptakan inovasi sebagai upaya pengembangan perpustakaan yang merupakan bagian dari tugas kepustakawanan. Kemampuan pustakawan untuk menggunakan teknologi informasi adalah kunci berjalannya sebuah layanan online. Pandemi Covid-19 ini tidak menyurutkan perpustakaan dan pustakawan untuk mengabaikan layanan kepada pemustaka. Penerapan protokol kesehatan yang ketat adalah salah satu solusi untuk tetap dilakukannya pelayanan kepada pemustaka dan penerapan layanan online yang sangat dianjurkan di era pandemi Covid-19.

\section{Daftar Pustaka}

Anggrahini, D. (2020). Kondisi UPT Perpustakaan Muhammadiyah Pontianak Pada Saat Terjadi Virus Corona (Covid-19). In New Normal Innovations: Adaptasi Perpustakaan Perguruan Tinggi Muhammadiyah 'Aisyiyah (hal. 26-34). Gramasurya.

Anindieta, R. P. (2020). Evolusi Perlayanan Perpustakaan Universitas Muhammadiyah Jakarta Di Era Pasca Pandemi Covid-19. In New Normal Innovations: Adaptasi Perpustakaan Perguruan Tinggi Muhammadiyah 'Aisyiyah (hal. 98-108). Gramasurya.

Badan Pengembangan dan Pembinaan Bahasa Kementerian Pendidikan Kebudayaan Riset dan Teknologi Republik Indonesia. (2021, Agustus 20). Kamus Besar Bahasa Indonesia. https://www.kbbi.web.id.

FPPTMA. (2021, Desember 7). Link Perpustakaan Perguruan Tinggi Muhammadiyah / Aisyiyah. http://www.fpptma.or.id/2017/07/link-perpustakaan-perguruantinggi_20.html.

Goeyardi, D. L. (2020, Oktober 29). Semua Tentang Generasi X (bagian 1). https://belajartrading.co.id. https://belajartrading.co.id/seputar-forex/read/semuatentang-generasi-X-bagian-1

Gottlieb, D. (1965). Innovation in Education. Matthew B. Miles. American Journal of Sociology, 71(2), 228-229. https://doi.org/10.1086/224067

Hariri, A. (2020). Transformasi Perpustakaan Perguruan Tinggi Di Masa New Normal (Studi Pada Perpustakaan UMP). In New Normal Innovations: Adaptasi Perpustakaan Perguruan Tinggi Muhammadiyah 'Aisyiyah (hal. 128-145). Gramasurya.

Hendrawan, M. R. (2013). Konflik Antarpribadi dan Pengaruhnya Terhadap Aspek Layanan pada Perpustakaan PDII-LIPI. Visi Pustaka, 15(2). https://www.perpusnas.go.id/magazine-detail.php?lang=id\&id=8291

IFLA. (2020, Oktober 19). COVID-19 and the Global Library Field. https://www.ifla.org. Indrakasih, R. I. (2020). Podcast Dengan Menggunakan Aplikasi Anchor: Pengembangan Kompetensi Pustakawan Perguruan Tinggi Dibidang Digital Storytelling, Digital Puisi Dan Digital Pengumuman. In New Normal Innovations: Adaptasi Perpustakaan Perguruan Tinggi Muhammadiyah 'Aisyiyah (hal. 10-18). Gramasurya.

Irkhamiyati. (2020). Aplikasi Work From Home Pustakawan UNISA Yogyakarta Selama Masa Pandemi Covid 19. In In New Normal Innovations: Adaptasi Perpustakaan Perguruan Tinggi Muhammadiyah 'Aisyiyah. Gramasurya. 
Jubaidi, M. (2020). Manifestasi Ilmu Pengetahuan Melalui LAM (Library,Archives dan Museum) Sebagai Diaspora Gerakan Abad Ke-2 Muhammadiyah. In New Normal Innovations: Adaptasi Perpustakaan Perguruan Tinggi Muhammadiyah 'Aisyiyah (hal. 1-10). Gramasurya.

Keputusan Menteri Kesehatan Republik Indonesia Tentang Protokol Kesehatan bagi Masyarakat di Tempat dan Fasilitas Umum dalam Rangka Pencegahan dan Pengendalian Corona Virus Disease 2019 (Covid-19), Pub. L. No. HK.01.07/MENKES/382/2020, 37 (2020).

Kementerian Pendidikan dan Kebudayaan Republik Indonesia. (2020, Desember 3). Perkuliahan Dapat Dilakukan Secara Tatap Muka dan dalam Jaringan Tahun 2021. https://www.kemdikbud.go.id. https://www.kemdikbud.go.id/main/blog/2020/12/perkuliahan-dapat-dilakukansecara-tatap-muka-dan-dalam-jaringan-tahun-2021

Layyina, L. (2020). Optimalisasi Layanan Prima Perpustakan Di Era New Normal Covid19. In New Normal Innovations: Adaptasi Perpustakaan Perguruan Tinggi Muhammadiyah 'Aisyiyah (hal. 19-25). Gramasurya.

Lhoksumawe, S. (2020, Agustus 23). Ini daftar Perguruan Tinggi MuhammadiyahAisyiyah dari Sabang sampai Marauke. https://stikeslhokseumawe.ac.id.

Muhammadiyah. (2021). Tentang Muhammadiyah. http://arsip.muhammadiyah.or.id/. http://arsip.muhammadiyah.or.id/id/content-44-cam-tentangmuhammadiyah.html

Mukerji, D., \& Robbins, S. (1994). Managing organisations : new challenges and perspectives. Prentice Hall.

Nisak, K. (2020). Sistem Pembayaran Dengan Perpustakaan Berbasis Mobile Payment Di Universitas 'Aisyiyah Yogyakarta: Suatu Pemikiran. In New Normal Innovations: Adaptasi Perpustakaan Perguruan Tinggi Muhammadiyah 'Aisyiyah (hal. 70-75). Gramasurya.

Nur, M. (2020). Kemas Ulang Modul Menjadi Video Pembelajaran Di Youtube Guna Mendukung Pembelajaran Jarak Jauh (PJJ) Di Era Pandemi. In New Normal Innovations: Adaptasi Perpustakaan Perguruan Tinggi Muhammadiyah 'Aisyiyah (hal. 146-154). Gramasurya.

Oktavia, W. (2021, Juli 1). Anjuran Masker Dobel, Mengapa Masker Medis Masih Perlu Dilapisi Masker Kain? Tempo. https://tekno.tempo.co/read/1478415/anjuranmasker-dobel-mengapa-masker-medis-masih-perlu-dilapisi-maskerkain/full\&view=ok

Oktavira, B. A. (2019, Oktober 19). Hukumnya Digitalisasi Buku Perpustakaan. https://www.hukumonline.com.

Pimpinan Pusat 'Aisyiyah. (2021). Sejarah 'Aisyiyah. Pimpinan Pusat 'Aisyiyah. https://aisyiyah.or.id/profile

Prasetyo, D. C. (2020). Perpustakaan, Pandemi dan Fiksi: Peran Perpustakaan Perguruan Tinggi Menghadapi Infodemi. In New Normal Innovations: Adaptasi Perpustakaan Perguruan Tinggi Muhammadiyah 'Aisyiyah (hal. 109-127). Gramasurya.

Purwono. (2013). Profesi Pustakawan Menghadapi Tantangan Perubahan. 2013.

Rahmawati, D. (2020). Sirkulasi Online Perpustakaan Pada SIMPTT Mahasiswa Universitas ‘Aisyiyah Yogyakarta Sebagai Inovasi Layanan Perpustakan Di Saat Pandemik Covid-19. In New Normal Innovations: Adaptasi Perpustakaan Perguruan Tinggi Muhammadiyah 'Aisyiyah (hal. 87-98). Gramasurya.

Undang-Undang Republik Indonesia Nomor 28 tahun 2014 tentang Hak Cipta, Pub. L. No. Nomor 28 Tahun 2014, Kementerian Sekretariat Negara RI (2014).

Satuan Tugas Penanganan COVID-19. (2021, Agustus 20). Peta Sebaran Covid-19. https://covid19.go.id. 
Setiawati, D. (2020). Peran Perpustakaan Digital di Masa Pandemi Covid-19. In New Normal Innovations: Adaptasi Perpustakaan Perguruan Tinggi Muhammadiyah 'Aisyiyah (hal. 47-57). Gramasurya.

Setiobudi, I. (2020). Pustakawan Menyapa dan Tanya Pustakawan sebagai Upaya Menangkal Hoaks Seputar Covid-19 Di Lingkungan UMP. In New Normal Innovations: Adaptasi Perpustakaan Perguruan Tinggi Muhammadiyah 'Aisyiyah (hal. 76-86). Gramasurya.

Sujatna. (2018). Inovasi Pustakawan Zaman Now. Mahara Publishing.

Sundari, Y. (2020). Pelayanan Perpustakaan Universitas Muhammadiyah Sukabumi Pada Masa Pandemi Covid-19. In New Normal Innovations: Adaptasi Perpustakaan Perguruan Tinggi Muhammadiyah 'Aisyiyah. Gramasurya.

Winata, A. P. (2019). Kejahatan Dunia Maya Bidang Akademik. Media Pustakawan: Media Komunikasi Antar Pustakawan, 26(4), 259-264. https://ejournal.perpusnas.go.id/mp/article/view/575

Winata, A. P., Gretha Prestisia R. K., \& Sulistyo-Basuki. (2019). Santri Islamic Boarding School Student's Information Behaviour In Yogyakarta (Indonesia): A Case Study. International Conference on Library and Information System: From Open Library to Open Society (iCOO 2018), 256-259. 